\title{
East meets west: competitive interactions between green crab Carcinus maenas, and native and introduced shore crab Hemigrapsus spp.
}

\author{
Gregory C. Jensen*, P. Sean McDonald, David A. Armstrong \\ School of Aquatic and Fishery Sciences, University of Washington, Box 355020, Seattle, Washington 98195, USA
}

\begin{abstract}
The recent introduction of the European green crab Carcinus maenas and Asian shore crab Hemigrapsus sanguineus to the west and east coasts of North America, respectively, presents a unique opportunity for investigation into competitive dynamics among intertidal crabs. Juvenile C. maenas utilize rocks, shell, and other cover, and their arrival on the west coast places them in potential competition for these resources with an abundant native grapsid, $H$. oregonensis. Similarly, $H$. sanguineus use intertidal shelter on the east coast, thus placing $C$. maenas in possible competition with grapsids both as an invader on the west coast and as 'resident' on the east coast, having been established there for more than 150 yr. Field sampling and laboratory experiments testing competition for space between C. maenas and Hemigrapsus spp. of equal carapace width were conducted on both coasts, as were videotaped feeding trials to examine and quantify agonistic interactions between species. When competing for food (a single damaged, anchored bivalve), C. maenas dominated over $H$. oregonensis, while $H$. sanguineus were overwhelmingly dominant over $C$. maenas. Within-quadrat, stratified sampling of rocks and sand revealed striking differences in habitat utilization by C. maenas living in the presence or absence of Hemigrapsus. Only $\sim 20 \%$ of juvenile C. maenas occurred under rocks in areas occupied by either Hemigrapsus species, while north of the present distribution of $H$. sanguineus (in Maine) $>97 \%$ of the $C$. maenas were found beneath rocks. This pattern was reflected in laboratory trials as well, where both species of Hemigrapsus consistently dominated in contests for shelter. Given the importance of intertidal cover for small crabs, such competitive interactions will likely affect patterns of habitat use by $C$. maenas on the east coast and may have important implications for the ultimate distribution and impact of this species in the northeastern Pacific.
\end{abstract}

KEY WORDS: Carcinus maenas · Hemigrapsus oregonensis $\cdot$ Hemigrapsus sanguineus $\cdot$ Interspecific competition $\cdot$ Intertidal $\cdot$ Nonindigenous crabs $\cdot$ Shelter

Resale or republication not permitted without written consent of the publisher

\section{INTRODUCTION}

The introduction of nonindigenous marine organisms is an area of growing concern, with recent studies indicating widespread and severe impacts in estuaries and coastal habitats (Carlton \& Geller 1993, Ruiz et al. 1997, 1999, Cohen \& Carlton 1998). Introduced marine species can affect native species in myriad ways,

\footnotetext{
*E-mail: gjensen@u.washington.edu
}

including direct predation (Race 1982), as vectors for parasites, diseases, and fouling organisms (Kuris \& Culver 1999), or as competitors for food (Byers 2000) or space (Hockey \& van Erkom-Schurink 1992, Geller 1999, Jousson et al. 2000).

While predation may have the most direct impact, other interactions may be of no less importance. Native species that are competitively displaced from preferred areas may face increased risk of predation and reduced access to food. For example, materials such as rocks, shells, and vegetation serve as protective cover 
for many species of decapod Crustacea, providing critical refuge from fish and other predators (Heck \& Thoman 1981, Fernandez et al. 1993a, Navarrete \& Castilla 1990, Thiel \& Dernedde 1994, Moksnes et al. 1998), as well as important substrates for prey (Iribarne et al. 1992, Perkins-Visser et al. 1996). A shortage of appropriately sized refuge space at some point during their benthic life can result in a bottleneck effect that limits populations (Wahle \& Steneck 1991).

Such shelter is particularly important for species inhabiting the intertidal zone, where in addition to aquatic predators, decapods must contend with shorebirds and other terrestrial organisms as well as a host of physical stresses. Small shelters provide moist microhabitats that help reduce desiccation (Grant \& McDonald 1979) and serve as a buffer against temperature changes (Taylor 1981, Abele et al. 1986), while crevices in large rocks can also shield against strong currents and wave impacts (O'Neill \& Cobb 1979).

The importance of shelter for survival in the intertidal is revealed by dramatic increases in crab densities following the addition of such material to a beach. An experimental doubling of the number of rocks in a given area resulted in more than a 4 -fold increase in the density of the shore crab Hemigrapsus sanguineus in Japan (Lohrer et al. 2000). In Washington State, USA, large amounts of oyster shell has been added to the intertidal zone of Grays Harbor in an attempt to create habitat for juvenile Dungeness crab Cancer magister (Wainwright et al. 1992, Dumbauld et al. 1993). Due to the combined effect of increased survival in shell and habitat selection (Fernandez et al. 1993b), density of newly settled C. magister may reach 400 crabs $\mathrm{m}^{-2}$ in intertidal shell, initially 2 to 3 orders of magnitude higher than in adjacent areas of sand or mud (Palacios et al. 2000). However, competition for this habitat is great, and the number of $C$. magister is dramatically reduced in subsequent years as the shell is colonized by high densities of the shore crab Hemigrapsus oregonensis (Visser 1997).

Although competitive exclusion is theoretically an important factor affecting the survival of decapod Crustacea (Caddy 1986), few studies have focused on this form of interaction between intertidal species requiring epibenthic shelter. Most investigations have been directed at freshwater (e.g. Bovbjerg 1970, Soderback 1991, Peeke et al. 1995) and subtidal (e.g. Thorpe 1976, Richards 1992, Beck 1997) habitats where increased predation risk is the primary concern. However, the outcome of competitive interactions may be more critical for intertidal species, which experience a greater array of stressors. The recent introduction of exotic shore crab species to the east coast (northwestern Atlantic) and west coast (northeastern Pacific) of North America (Williams \& McDermott 1990,
Grosholz \& Ruiz 1995, Cohen et al. 1995) add new potential competitors for limited intertidal shelter.

The European green crab Carcinus maenas was found in San Francisco Bay, California, in 1989, and has since spread south to Morro Bay and as far north as Nootka Sound on Vancouver Island, British Columbia (G.S. Jamieson pers. comm.); based solely on the physiological tolerance of this species, it is estimated to have a potential range on the west coast from Baja California to the Aleutian Islands (Cohen et al. 1995). The arrival and range expansion of this species on the west coast has been cause for concern among ecologists, resource managers, and the aquaculture industry. Much of this stems from impacts following its introduction to the east coast of North America nearly 200 yr ago (Cohen et al. 1995). On that coast, it has had measurable effects on the morphology of intertidal snails (Vermeij 1982, Trussell 1996), and is believed to have had a serious impact on bivalve culture operations (Glude 1955, Hanks 1961).

In its native waters, juvenile Carcinus maenas often occur under rocks and shells in the intertidal zone (Crothers 1968, Klein-Breteler 1976, Thiel \& Dernedde 1994), a location that would place those on the west coast of North America in potential competition for space with several species of grapsid crabs. However, during qualitative surveys of beaches in Bodega Bay Harbor and Tomales Bay, California, juvenile C. maenas appeared to make little use of spaces beneath rocks, which were occupied instead by large numbers of the native shore crabs Hemigrapsus oregonensis and, to a much lesser extent, Pachygrapsus crassipes. A sampling program that concentrated on microhabitat use by juvenile $C$. maenas was initiated to investigate the possible influence of these native grapsids on the use of shelter by C. maenas. Laboratory experiments concentrated on interactions with $H$. oregonensis because this species has the greatest overlap with $C$. maenas in both habitat type and potential geographic range, and since both species readily colonize epibenthic intertidal shell (Thiel \& Dernedde 1994, Visser 1997).

At about the same time that Carcinus maenas was becoming established on the west coast, an Asian shore crab, Hemigrapsus sanguineus, was found in New Jersey (Williams \& McDermott 1990). This grapsid species quickly became the most abundant intertidal crab in some areas (Lohrer \& Whitlatch 1997, Ahl \& Moss 1999), and now ranges from Cape Cod, Massachusetts, to Oregon Inlet, North Carolina (McDermott 1998). The intertidal distribution of this species overlaps that of juvenile $C$. maenas, particularly in the northern part of their range (Lohrer \& Whitlatch 1997, McDermott 1998); furthermore, H. sanguineus is dependant on rock cover (Lohrer et al. 2000) and anecdo- 
tal reports from bait collectors and others have suggested that $C$. maenas has become uncommon under rocks in some areas after the arrival of $H$. sanguineus. Although potential for competitive interactions for space and/or food between these 2 species has often been noted (McDermott 1991, 1998, 1999, Lohrer \& Whitlatch 1997), tests designed to address these questions have not been reported.

These bi-coastal introductions provide a unique and valuable 'natural' experiment that can be used to examine the relationship between an established species and a novel competitor, as well as possible effects of competition on habitat use and the distribution of both species. This study was initiated to investigate potential competition for shelter between these species by conducting similar types of sampling and experiments on both coasts. Specifically, we sought to test the hypothesis that the presence of grapsids influences the use of shelter by juvenile Carcinus maenas by comparing microhabitat use in areas where they coexist to an area where the other species is absent, and by examining one-on-one competition for shelter between the species in controlled experiments. This was augmented by videotaping staged contests over food in the laboratory to more closely examine interactions between species and provide a means to quantify agonistic behaviors. Previous work of this type has already revealed the dominance of juvenile C. maenas over Cancer magister of equal size when competing for food or space (McDonald et al. 2001).

Finally, a series of oyster shell plots were deployed in Bodega Bay Harbor to further examine the potential for Carcinus to utilize this type of habitat. Over 60 ha of oyster shell have been placed in Grays Harbor, Washington, to create habitat for juvenile Cancer magister and mitigate for those killed by dredging operations (Wainwright et al. 1992, Dumbauld et al. 1993); as noted earlier, these areas were subsequently inhabited by high densities of Hemigrapsus oregonensis that in turn largely excluded the target species (Visser 1997). By examining crab densities and species composition through time in the Bodega Bay Harbor shell plots, we hoped to gain some insight into the likelihood of Carcinus maenas colonizing these areas in Washington State or similar situations.

\section{MATERIALS AND METHODS}

Field sampling. Quantitative sampling of Carcinus maenas and native crab populations was conducted in Bodega Bay Harbor, California (Fig. 1), a shallow embayment with minimal wave exposure similar to many other protected bays and estuaries along the west coast. Crabs were sampled in 2 areas of the harbor

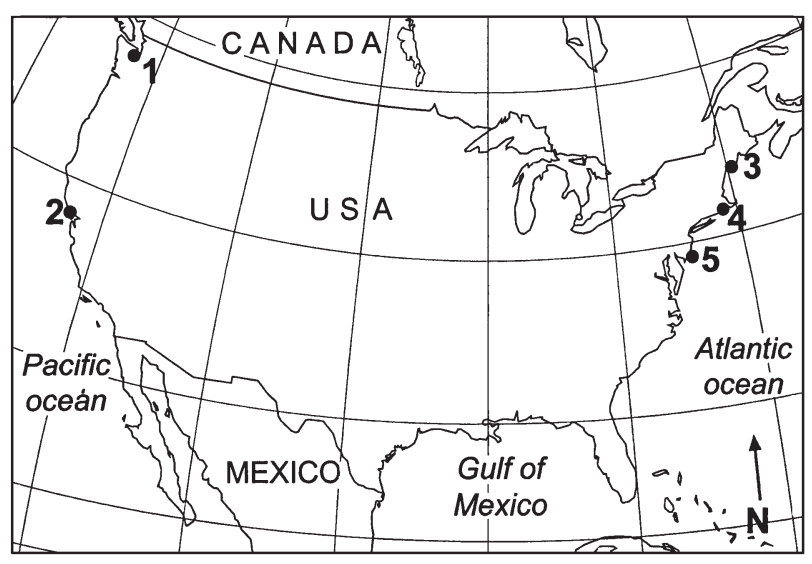

Fig. 1. Map showing locations of field sampling sites on the west coast (northeast Pacific) and east coast (northwest Atlantic) of North America. 1 = Brownsville, Washington; $2=$ Bodega Bay Harbor, California; 3 = Darling Marine Center, Walpole, Maine; 4 = Demarest Lloyd State Park, South Dartmouth, Massachusetts; and $5=$ Grassy Sound Bridge, Stone Harbor, New Jersey

where rocks of moderate size $(\sim 20$ to $30 \mathrm{~cm}$ longest axis) were resting on slightly muddy sand; overall rock cover in the areas averaged $\sim 20 \%$. Samples were taken randomly at the $\mathrm{m}$ MLLW +1.2 tidal level using a $0.25 \mathrm{~m}^{2}$ quadrat frame. An estimate of \% rock cover and \% algae cover was made prior to sampling each quadrat; in those that contained rocks these typically comprised 20 to $40 \%$ of the surface area. To determine the percentage of crabs using shelter within each quadrat, the sediment immediately beneath the rocks and that surrounding the rocks was processed separately, as follows: before moving any rocks, all areas of bare sediment within each quadrat were excavated to a depth of $\sim 6 \mathrm{~cm}$ and sieved using a $1.0 \mathrm{~mm}$ screen. The rocks were then carefully lifted, all visible crabs beneath them caught by hand, and the sediment directly beneath the rocks also removed and sieved. All crabs found were identified, measured (maximum carapace width, CW), and sexed. A total of 12 samples were taken during each sampling period and sampling was conducted in May and June 1998, and monthly from June 1999 to August 2000.

Sampling locations were sought on the east coast that had rock and sediment characteristics very similar to the site in Bodega Bay Harbor (Fig. 1). Selection of appropriate tide heights for sampling was complicated by the great differences in tidal amplitude at the different locations, both within and between coasts. Instead of establishing an absolute tide elevation for each site, samples were confined to areas immediately above the distribution of mud crabs (Xanthidae; primarily Eurypanopeus depressus), which are most abundant below the mean tide level (Lohrer \& Whitlatch 
1997). This removed the confounding factor of a third potential competitor for space and simplified comparison of habitat use by Hemigrapsus and Carcinus, which are both common at these higher levels.

The limited time available for east coast sampling precluded us from conducting a long-term program as was done in Bodega Bay Harbor, and necessitated a slight change in methods. At Bodega, the scattered rocks in the sampling areas covered only a small portion of the total surface; thus, the random placement of the quadrat frame resulted in much time spent sampling areas of open sediment that had no crabs. Our selection of areas on the east coast that had physical characteristics similar to Bodega meant that random sampling would have provided too few rocks for a meaningful comparison. Since our focus was on microhabitat use as revealed by the stratified, withinquadrat sampling method described above, the quadrat frame was instead randomly oriented over rocks of appropriate size and the rest of the procedure remained the same. Rock typically comprised 20 to $40 \%$ of the surface area of the quadrat. Sampling was conducted in late August-early September 1999 near the Darling Marine Center, Walpole, Maine (17 samples), at Demarest Lloyd State Park, South Dartmouth, Massachusetts (17 samples), and Grassy Sound Bridge, Stone Harbor, New Jersey (12 samples). Additional randomized samples of bare sediment at the same tidal elevation and 3 to $5 \mathrm{~m}$ away from all cover were taken at each site for comparison to the bare sediment samples from Bodega Bay Harbor.

Finally, to better define habitat use by Hemigrapsus oregonensis in the absence of Carcinus maenas, additional west coast samples were taken near Brownsville, Washington in Puget Sound, where C. maenas is not yet present (Fig. 1). Rock size, spacing and sediment composition at this site appeared identical to the site in Bodega Bay Harbor, and 10 samples were taken from the $+1.5 \mathrm{~m}$ MLLW tide level in March 2001. Differences in the proportion of crabs within or outside rock shelter were compared between sites for $H$. oregonensis and C. maenas on the west and east coasts, respectively, using appropriate statistical procedures (Z-statistic; Zar 1984).

Shelter competition. Competitive interactions between Hemigrapsus oregonensis and Carcinus maenas were examined using crabs collected from Bodega Bay Harbor, and placed in containers $(28 \mathrm{~cm}$ bottom diameter) immersed in a large outdoor pool supplied with ambient seawater at the Bodega Marine Lab. Each of 14 treatment containers received a male $H$. oregonensis (14.1 to $20.3 \mathrm{~mm}$ ) and a juvenile C. maenas (14.3 to $20.6 \mathrm{~mm}$ ) of equal or slightly greater $\mathrm{CW}$, while the 28 interspersed controls contained single specimens of either species, of a similar size range. Since prelimi- nary tests comparing juvenile male and female $C$. maenas of this size revealed no differences in behavior nor sexual dimorphism in chela size, males and females of this species were randomly assigned to treatments and controls. Each container had $\sim 3 \mathrm{~cm}$ of sand in the bottom and a single bivalve shell (Macoma balthica), about twice the CW of the crabs used, in the middle. Experiments ran for $24 \mathrm{~h}$, over which time the pools were slowly drained and filled twice to simulate ambient high and low tides for the area; screened openings near the bottom of the individual containers allowed them to drain fully. Crabs were not fed during this period. Position of the crabs relative to the shell was noted during the second 'low' tide, and a crab was judged to be occupying the shell if: (1) it was buried in the sand under a shell or, (2) a body surface of the crab directly abutted the plane of the shell. Crabs were also examined for limb damage and/or mortality.

Competition for shelter between male Hemigrapsus sanguineus and juvenile Carcinus maenas was investigated in the same manner using similar containers $(25 \mathrm{~cm}$ diameter) in a large outdoor tank at the University of Delaware's Hugh R. Sharp campus in Lewes, Delaware, with 15 each of single-species controls and 15 mixed-species treatments. All crabs were collected from a beach adjacent to the laboratories, and ranged in size from 13.0 to $19.7 \mathrm{~mm} \mathrm{CW}$; Mercenaria mercenaria shells were used in this experiment. The number of crabs utilizing the shell in both experiments was analyzed by heterogeneity chi-square analysis of a $2 \times 2$ contingency table (Zar 1984).

Shell plots. To investigate colonization of epibenthic shell by intertidal crabs, 5 shell plots $\left(3 \mathrm{~m} \times 3 \mathrm{~m}_{i} \sim 25 \mathrm{~m}\right.$ apart) were constructed at the +0.6 m MLLW tide level in Bodega Bay Harbor. The plots were made up of a $\sim 12 \mathrm{~cm}$ thick layer of clean, dry Pacific oyster Crassostrea gigas shells that were placed on open muddy sand substrate $>200 \mathrm{~m}$ from any rock habitat. From the 36 possible $0.25 \mathrm{~m}^{2}$ quadrats within each plot, 2 quadrats were selected using random numbers and sampled; sampling was done once each month and contiguous quadrats were never used in consecutive sampling periods. Shell was carefully removed and examined for crabs, and the underlying sediment excavated to a depth of $\sim 6 \mathrm{~cm}$ and sieved using a $1.0 \mathrm{~mm}$ screen. All crabs were measured to the nearest $0.1 \mathrm{~mm}$, and all shell, sediment, and crabs returned to the quadrat. Monthly mean densities of Carcinus maenas and Hemigrapsus oregonensis within shell plots were compared using a paired $t$-test.

Feeding interactions. To observe and record interactions between the different species and as another gauge of competitive ability, crabs were videotaped as they competed for a single, anchored bivalve. Three 
different feeding experiments were conducted using male Hemigrapsus spp. and juvenile Carcinus maenas: (1) C. maenas from Bodega Bay Harbor versus $H$. oregonensis from the same location; (2) C. maenas and $H$. sanguineus collected from the same beach in Delaware; and (3) C. maenas from Maine (where H. sanguineus is not yet found) versus $H$. sanguineus from Delaware. All crabs were used only once. Feeding experiments were conducted within either $10.8 \mathrm{~cm}$ (for crabs 9.9 to $11.9 \mathrm{~mm} \mathrm{CW}$ ) or $20 \mathrm{~cm}$ (for crabs 12.3 to $23.8 \mathrm{~mm} \mathrm{CW}$ ) diameter containers, containing a $\sim 2 \mathrm{~cm}$ layer of sand. Crabs were starved for $24 \mathrm{~h}$ prior to being used.

All replicate trials of each experiment were conducted in the dark, when all 3 species seemed to be most active and responsive to bait. For each trial, crabs of equivalent carapace width were placed in the container and allowed to acclimate for $20 \mathrm{~min}$ before the addition of bait. The bait consisted of a single small bivalve (Mytilus spp. or Tapes phillipanarium), no longer than the $\mathrm{CW}$ of the crabs being tested) that had been drilled through the center and attached with a wire to a small square $(\sim 25 \mathrm{~mm} \times 25 \mathrm{~mm})$ of hard plastic. The plastic was pushed well beneath the sand and served to anchor the bait in place on the surface of the sand, thus maximizing interactions between the crabs by preventing either one from carrying the bait away. Although the drill hole provided a useful means to attach the bivalve to the anchor, the primary reason for drilling was to release scents to elicit a strong feeding response from the crabs.

Trials were videotaped using a stationary SONY, CCD camera, equipped with an infrared light (>820 nm), and tapes were analyzed for the following: (1) first to find bait; (2) number of successful and unsuccessful attempts to feed on the bait; (3) number of times a crab successfully displaced the other from the bait; and (4) total amount of time each crab fed on the bait. The latter was the proportion of time each crab spent feeding after both crabs had discovered the bait, and trials ended when one of the crabs abandoned the bait without provocation. Trials in which either crab showed no interest in the bait were discarded, and the remainder were analyzed as follows: a binomial test was used to test the hypothesis of no difference $(p=0.05)$ in the ability of crabs to find the bait first. The proportion of successful attempts to feed on the bait (approaches) was compared among trials for east coast and west coast experiments using Wilcoxon paired-sample tests ( $T$-statistic), while the number of unsuccessful approaches by $C$. maenas from Maine and Delaware was compared with a 2 -sample $t$-test on square-root transformed data. Wilcoxon paired-sample tests were also used to compare the number of displacements by crabs in each

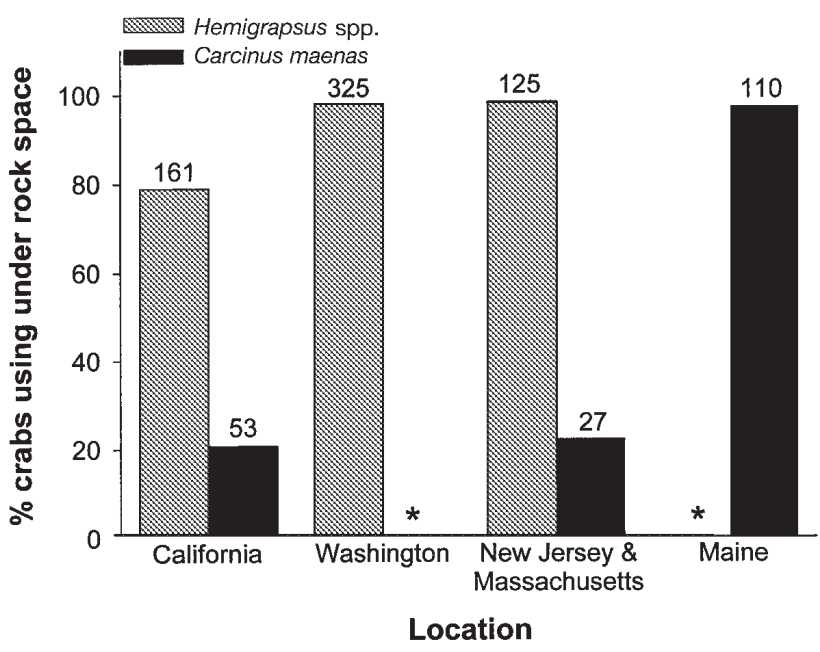

Fig. 2. Use of the under-rock microhabitat by Hemigrapsus spp. and Carcinus maenas in bi-coastal intertidal sampling. $H$. oregonensis and C. maenas occur in California, and only $H$. oregonensis occurs at the site sampled in Washington (west coast), while $H$. sanguineus and C. maenas inhabit New Jersey and Massachusetts, and only $C$. maenas occurs in Maine (east coast). Values above bars are total number of crabs found beneath rocks during sampling in that location (* indicates that $C$. maenas and $H$. sanguineus are not yet found at these sites on the west and east coasts of North America, respectively)

experiment. Proportional time spent feeding by each crab was arcsine (square-root) transformed and compared using paired $t$-tests for both east coast and west coast trials.

\section{RESULTS}

\section{Field sampling}

Only $20 \%$ of the juvenile Carcinus maenas uncovered during sampling in Bodega Bay Harbor were collected from beneath rocks, with the rest found buried in sand immediately adjacent to the rocks; in contrast, $79 \%$ of the Hemigrapsus oregonensis were found underneath rocks (Fig. 2). A similar pattern was found in New Jersey and Massachusetts, where $22 \%$ of the $C$. maenas occurred beneath rocks while $98 \%$ of the Hemigrapsus sanguineus collected in these areas utilized this shelter. In Maine, north of the present range of $H$. sanguineus and where $C$. maenas was the only species of crab found in our quadrats, $97.3 \%$ of the juveniles were found beneath rocks. The proportion of $C$. maenas under rocks was significantly higher in Maine than New Jersey and Massachusetts $(Z=10.1620, \mathrm{p}<0.0001)$. There was no difference in size or color between those $C$. maenas utilizing shelter or not at any of the sites. In Puget 


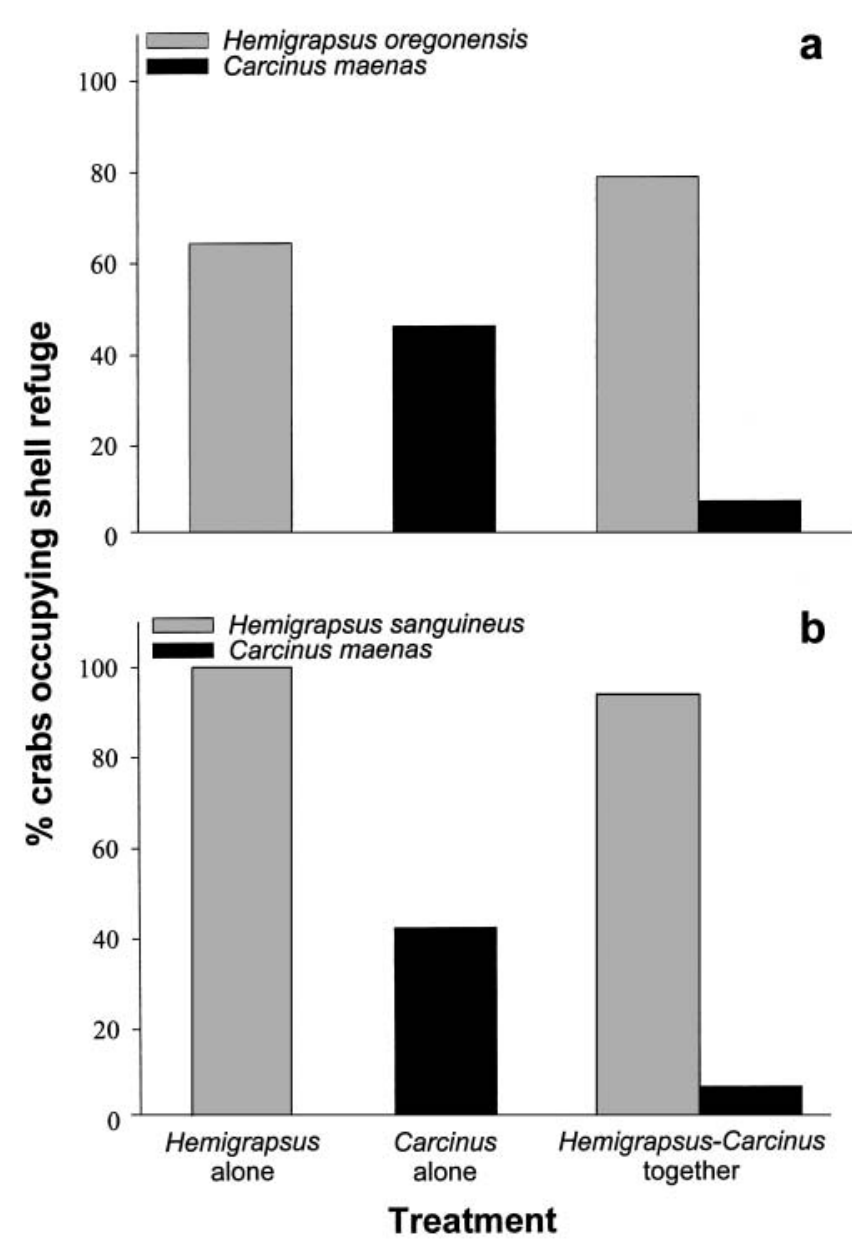

Fig. 3. Use of shell refuge by Carcinus maenas and Hemigrapsus spp. of similar size ( 15 mm CW) in the habitat competition experiments. Bars represent the percentage of crabs occupying the shell refuge after $24 \mathrm{~h}$. Treatments with only 1 crab species are controls for crab interaction. (a) West coast competition experiment between $C$. maenas and $H$. oregonensis ( $\mathrm{n}=14$ for each treatment). (b) East coast competition experiment between C. maenas and H. sanguineus ( $\mathrm{n}=15$ for each treatment)

Sound, where C. maenas is not yet present, H. oregonensis was the only crab species found in the samples and $98 \%$ of them were underneath rocks. A significantly higher proportion of $H$. oregonensis occupied space under rocks in Washington than California $(Z=7.1786, \mathrm{p}<0.0001)$. No crabs were found within quadrats placed on open sediment at any of the locations on either coast.

\section{Shelter competition}

Only $7.0 \%$ of the Carcinus maenas juveniles held with Hemigrapsus oregonensis were found beneath the shell, compared to $46 \%$ in the C. maenas-only controls (Fig. 3a; $\chi^{2}=4.762, p=0.029$ ). However, the presence of $C$. maenas did not have a significant effect on the use of the shell by $H$. oregonensis $\left(\chi^{2}=0.700 ; \mathrm{p}=\right.$ 0.402). Similarly, only $6.6 \%$ of the C. maenas confined with $H$. sanguineus utilized the shell, while $42 \%$ of

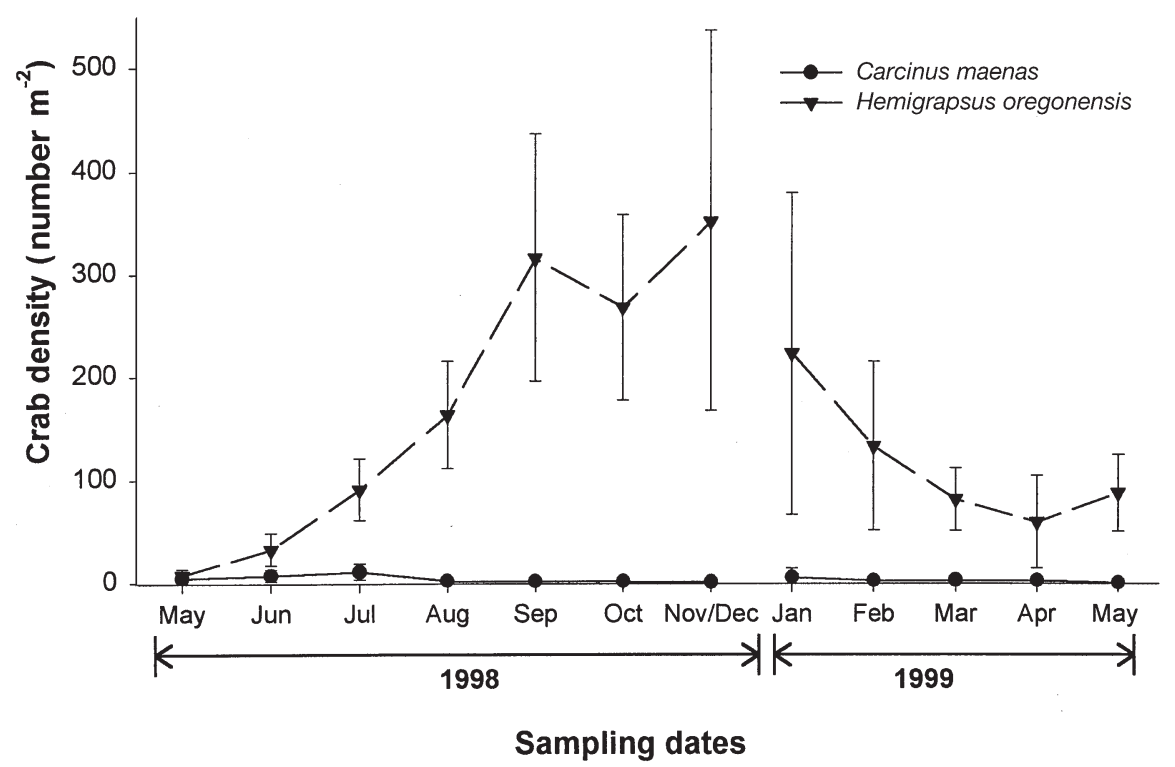

Fig. 4. Densities $\left(\mathrm{m}^{-2} \pm 1 \mathrm{SD}\right)$ of Hemigrapsus oregonensis and Carcinus maenas in Bodega Bay Harbor oyster shell plots 
those in controls used the shells as shelter (Fig. $3 b_{;} \chi^{2}=6.136, p=0.013$ ); the presence of C. maenas had no effect on shell utilization by $H$. sanguineus $\left(\chi^{2}=1.034, p=0.309\right)$.

\section{Shell plots}

Significantly more Hemigrapsus oregonensis occupied the shell plots constructed in Bodega Harbor than did Carcinus maenas $(t=$ $4.45, \mathrm{p}=0.0010$ ). The plots were quickly colonized by large numbers of $H$. oregonensis (Fig. 4), attaining densities as high as $625 \mathrm{~m}^{-2}$. C. maenas numbers were very low initially (highest density $10.8 \mathrm{~m}^{-2}$ ) and they were essentially absent after 5 mo. Densities of crabs were greatly reduced after the shell plots were partly dispersed and buried by winter storms.

\section{Feeding interactions}

In feeding trials involving Carcinus maenas and Hemigrapsus oregonensis, both crabs responded to the bait in 15 of 20 trials. Neither species showed an advantage in locating the bait first ( $p>99.99$ ). However, $C$. maenas spent a significantly greater amount of time at the bait than $H$. oregonensis, feeding an average of $73 \%$ of the time compared to only $27 \%$ of the time for the latter ( $t=$ 2.550, $p=0.0233$; Fig. 5a). C. maenas were also more likely to successfully approach a feeding competitor than were $H$. oregonensis (Wilcoxon $T=17, \mathrm{p}=0.0001$; Fig. 5b); 77.2\% and $40.1 \%$ of the approaches were successful for $C$. maenas and $H$. oregonensis, respectively. There was no difference in the frequency of displacements among species in the west coast trials (Wilcoxon $T=32.5$, $\mathrm{p}=0.5347$; Fig. 5b).

In contests between Carcinus maenas and Hemigrapsus sanguineus, both crabs responded to the bait in 26 of 36 trials; of these, C. maenas discovered the bait first in 19 of the runs ( $p=0.0288)$. Despite this advantage, the presence of $H$. sanguineus had a significant impact on $C$. maenas feeding time $(t=6.81, \mathrm{p}<$ 0.0001; Fig. 5a), and the latter spent less time $(15 \%)$ feeding than did the former $(84 \%)$. C. maenas were less likely to initiate contact with the bait while the other crab fed compared to $H$. sanguineus (Wilcoxon $T=2, p=0.0239 ;$ Fig. 5b). Although most approaches by $H$. sanguineus were successful $(95.0 \%)$ while $C$.
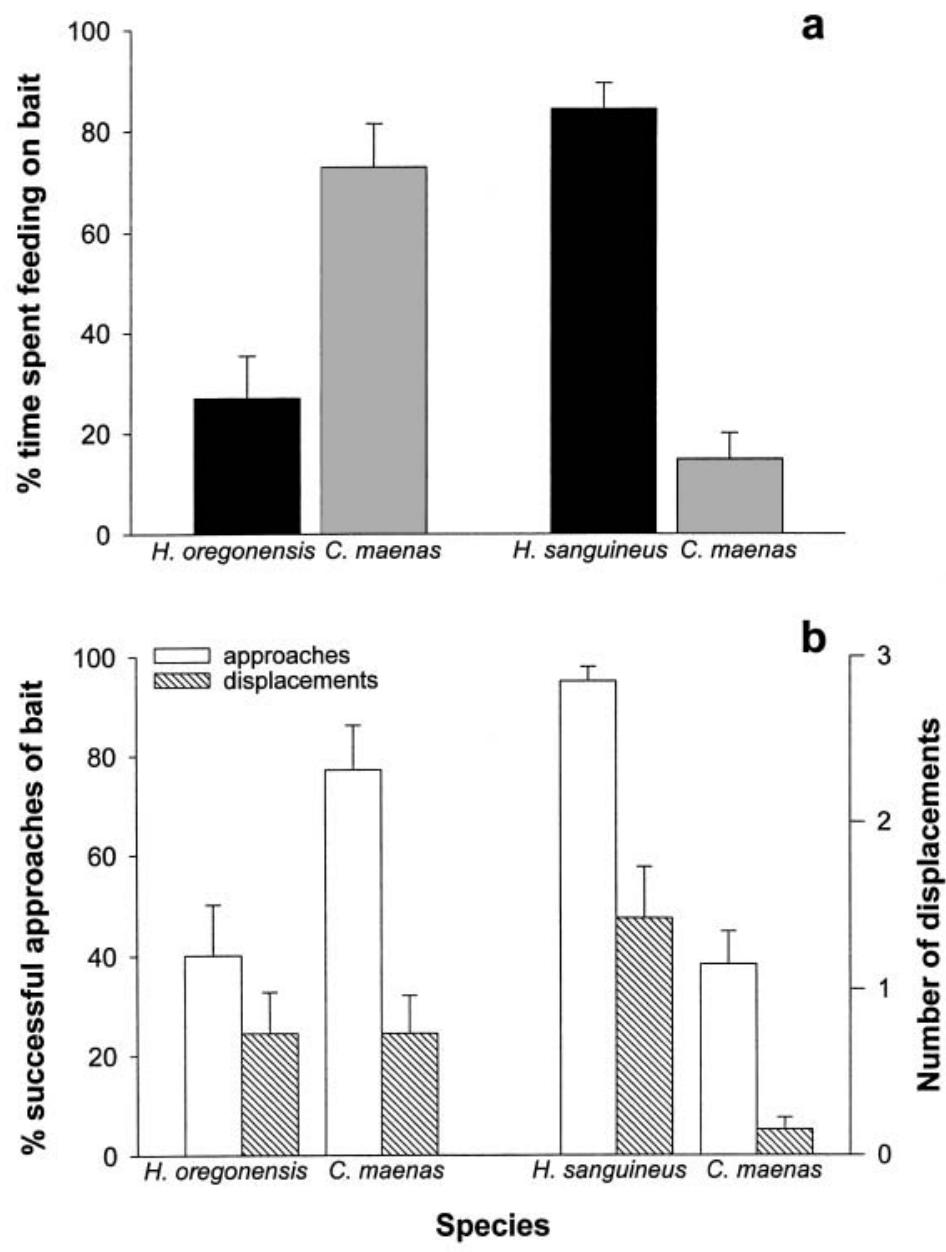

Fig. 5. Feeding behavior of pairs of Carcinus maenas and Hemigrapsus oregonensis and pairs of $C$. maenas and $H$. sanguineus competing for drilled, anchored bivalves in west coast $(n=15)$ and east coast $(n=26)$ video observations, respectively. (a) The mean percentage ( $\pm 1 \mathrm{SE}$ ) of time each crab spent feeding after both crabs had contacted the bait. (b) Two measures of crab interaction in observations of food competition: mean percentage of successful approaches (instances each crab initiated contact with the bait), and mean frequency of displacements when one species forced its competitor to retreat from the bait. Error bars indicate $\pm 1 \mathrm{SE}$ for both measures

maenas fed, approaches by the latter were less successful $(38.3 \%)$.

There were differences in the frequency with which each species displaced the other from the bait in the east coast trials (Wilcoxon $T=0, \mathrm{p}<0.0001$; Fig. 5b). Carcinus maenas were forced to retreat significantly more often per trial $(1.42 \pm 0.30 \mathrm{SE})$ than their Hemigrapsus sanguineus competitors $(0.15 \pm 0.07 \mathrm{SE})$. C. maenas from Maine also displayed far more persistence in their efforts to displace $H$. sanguineus from the bait than those from Delaware $(t=3.570, p=0.0016$; Fig. 6$)$, as reflected in the mean number of unsuccessful approaches of the bait, $7.08 \pm 1.40 \mathrm{SE}$ and $1.93 \pm 0.66 \mathrm{SE}$, respectively. 


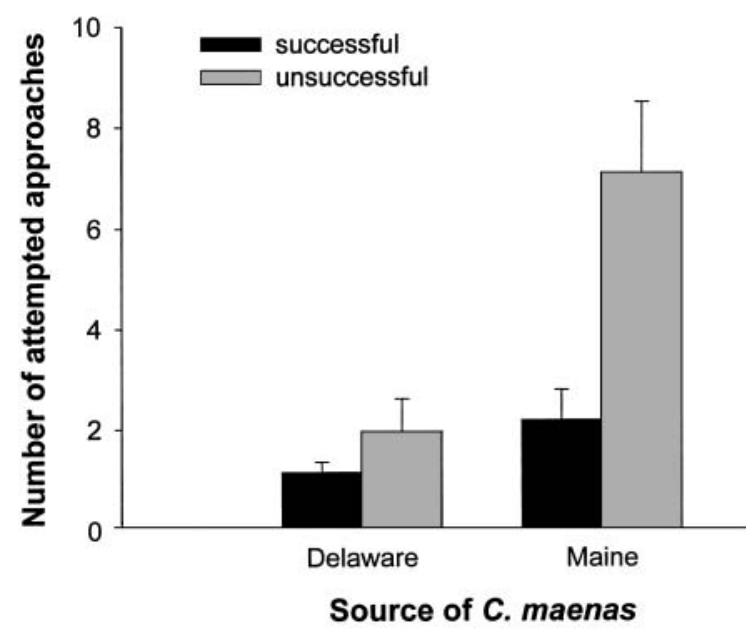

Fig. 6. The mean number of successful and unsuccessful attempts at the bait by Carcinus maenas from 2 locations in east coast video observations. C. maenas from Delaware $(\mathrm{n}=$ 14) were collected from an area inhabited by Hemigrapsus sanguineus, and presumably have previous experience with that species. C. maenas from Maine $(\mathrm{n}=12)$ were collected from an area outside the current range of $H$. sanguineus. Error bars indicate $\pm 1 \mathrm{SE}$

\section{DISCUSSION}

The results of the field sampling and laboratory competition experiments strongly suggest that both species of Hemigrapsus have a significant influence on the use of intertidal shelter by juvenile Carcinus maenas. In one-on-one competition for space, $H$. oregonensis and $H$. sanguineus were dominant over $C$. maenas, and the potential for competitive exclusion becomes especially apparent considering that these 2 grapsids are gregarious and typically live in large assemblages beneath rocks. In the present study, densities of $H$. sanguineus beneath rocks were as high as 190 crabs $\mathrm{m}^{-2}$ at Demerest Lloyd State Park, Massachusetts, and densities as high as $320 \mathrm{~m}^{-2}$ have been reported in New Jersey (McDermott 1998). Under-rock densities of $H$. oregonensis at the Puget Sound site (where C. maenas was absent) averaged $472 \mathrm{crabs}^{-2}$, and this species reached densities as high as $624 \mathrm{crabs} \mathrm{m}^{-2}$ in the Bodega Bay Harbor oyster shell plots.

Based on the dramatic increase in numbers of juvenile Carcinus maenas observed in Europe following the addition of shell to a beach (Thiel \& Dernedde 1994), one might have expected large numbers of Carcinus to utilize the oyster shell plots we constructed in Bodega Bay Harbor. C. maenas did initially colonize the plots in low numbers, but soon disappeared as the Hemigrapsus oregonensis population grew.

Although our sampling on the east coast was temporally limited, the similarity of patterns there compared to those found in the long-term sampling at Bodega Bay Harbor is striking. Juvenile Carcinus maenas collected within the present range of Hemigrapsus sanguineus were primarily buried in sand immediately adjacent to rocks, while nearly all of the C. maenas were beneath rocks in similar habitat in Maine where $H$. sanguineus was absent. C. maenas juveniles found in Bodega Bay Harbor were also in the sand between rocks rather than beneath, and on both coasts no crabs were found in samples from nearby flat, open areas of sand or mud that lacked shelter. It is likely that the competitive dominance of Hemigrapsus reflects a greater dependence on shelter as compared to C. maenas, since neither species of Hemigrapsus appears able to bury in sand as quickly or as completely as C. maenas. It would be especially useful to investigate the relative costs and benefits of competing for shelter for these species in the presence of predators. The lack of predators or other stimuli may account for the reduced use of shelter by the control C. maenas and $H$. oregonensis in the shelter experiments, relative to those sampled in the field.

Since the focus of this study was a bi-coastal examination of Carcinus maenas-Hemigrapsus interactions, much of our effort was directed at finding sites having physical characters (e.g. rock size, sediment composition) as similar as possible for comparison. Rocks of appropriate size were uncommon in southern New England, and many were unsuitable due to the coarseness of their underlying substrate. In these cases juvenile $C$. maenas could sometimes be found among dense coverings of Fucus spp. on the sides and tops of rocks and concrete slabs, but were absent from the undersides which were populated with $H$. sanguineus. These areas were not quantitatively sampled because we have not yet observed C. maenas on similar coarse substrates on the west coast. Lohrer \& Whitlatch (1997) also found high densities of $H$. sanguineus and very few or no C. maenas at sites where the beach consisted only of rock and gravel. However, they pointed out that their sites were fairly high-energy beaches that may never have supported large numbers of C. maenas, since this species largely avoids areas with high wave impact (LeRoux et al. 1990, Griffiths et al. 1992, Cohen et al. 1995). During our search we examined a number of rocky areas in sheltered waters (various jetties and other manmade structures) where $H$. sanguineus appeared to be the only crab present in the mid- to upper intertidal zone, while in Maine we observed that similar rocky areas in protected waters harbored large numbers of $C$. maenas of all sizes.

The labor intensive sampling method described here could yield important insights into the competitive interactions of these species, especially if applied in a time series on beaches just beyond the current range of 
Hemigrapsus sanguineus. Without the within-quadrat stratification of the samples, a subtle but potentially important shift in habitat use would not have been detected. In retrospect, we also believe it would have been useful to keep separate counts for each rock within the quadrats, since the few Carcinus maenas that were present under rocks were usually under ones lacking $H$. sanguineus. C. maenas now faces potential competition in its native waters with the recent introduction to Europe of another Asian grapsid, H. penicillatus (Noël et al. 1997, Gollasch 1999), and these methods could be useful in examining this interaction as well.

When competing for food against Hemigrapsus sanguineus, Carcinus maenas was usually the first to find the bait yet was almost invariably dislodged shortly thereafter by $H$. sanguineus. This typically did not involve overt aggression or chelae displays on the part of the $H$. sanguineus, but rather the use of the body and legs as a wedge to displace the $C$. maenas from the food. $H$. sanguineus rarely used their chelae for grasping their opponent or defending the bait; rather, approaching $C$. maenas were fended off with kicks from the walking legs while the chelae continued to be used for feeding. C. maenas often used a lateral merus display (Wright 1968) when approaching a feeding $H$. sanguineus and also sometimes used this display when defending the bait. $H$. oregonensis were much more hesitant in their approaches, usually tapping the C. maenas using closed chelae.

Although not measured quantitatively, it was apparent that Carcinus maenas were able to break into the bivalves more quickly than either species of Hemigrapsus. The bivalves used in our experiments had been drilled to both allow them to be anchored and to release scents to stimulate feeding, and the crabs typically attacked this damaged area first. The proportionately slimmer chelae of $C$. maenas appeared to be better suited to fit into the hole and enlarge it by chipping. This advantage apparently applies to undamaged bivalves as well, since McDermott (1999) noted that despite having similar measures of mechanical advantage, $C$. maenas were able to open larger mussels than comparably sized $H$. sanguineus.

The difference in behavior between Carcinus maenas from Delaware and those collected in Maine, relative to Hemigrapsus sanguineus, was especially interesting. C. maenas from Maine (which had never before encountered $H$. sanguineus) were very aggressive and persistent in their attempts to dislodge $H$. sanguineus from the bait, though their efforts did not result in any greater success. In contrast, the Delaware C. maenas appeared hesitant to challenge $H$. sanguineus and would typically make only 1 or 2 attempts while continuing to circle the bait. Considering both the proximity of the 2 species and the high densities of $H$. sanguineus at the collection site in Delaware, juvenile C. maenas there would almost certainly encounter them on a daily basis. It is possible this difference in behavior reflects a learned response in which $C$. maenas recognizes $H$. sanguineus as a superior competitor and avoids direct conflict. Such interspecific recognition has rarely been studied in Crustacea, however, Caldwell (1982) found that based on the outcome of previous agonistic contests with a competing species over shelter, the stomatopod Gonodactylus zacae could recognize specific individuals of the other species by scent alone.

The different outcomes of feeding interactions on the east and west coasts may be due to diet preferences of the 2 species of Hemigrapsus. Stomach content and fecal analysis of $H$. sanguineus from New Jersey (McDermott 1998, 1999) revealed a diet of primarily plant material, mussels, and barnacles, hence a strong dietary overlap with juvenile Carcinus maenas (Rangeley \& Thomas 1987, Lohrer \& Whitlach 1997). In contrast, Knudson (1964) analyzed stomach contents of $H$. oregonensis and found only sessile diatoms and algae, and only the smallest snails and newly-settled bivalves appear to be vulnerable to this species (Quayle 1988, Sousa 1993, Behrens Yamada \& Boulding 1996, 1998). Although both grapsids have claws with spoon-shaped tips suitable for scraping organisms from rocks, the chelae of $H$. sanguineus have a substantial mechanical advantage over those of $H$. oregonensis (Behrens Yamada \& Boulding 1998, McDermott 1999). This could possibly account for the former species' greater range of invertebrate prey and more pronounced dietary overlap with $C$. maenas.

Behavioral interactions away from the food were quite revealing as well. Regardless of the outcome of competition and once the food had been consumed, Hemigrapsus of both species would often excavate a shallow depression next to the side of the container and defend this area from Carcinus maenas. Even $H$. oregonensis that had been very timid during the feeding trial would remain in place and exclude $C$. maenas from their territory, behavior consistent with their dominance in the shelter experiment.

The feeding experiments described here were designed to initiate and maximize behavioral interactions between the species, not to mimic actual trophic competition in the wild. While displacements from small prey items could occur under natural situations (e.g. a mussel still anchored with byssal threads; damaged barnacles attached to a large rock), in most cases the crabs would have the option of fleeing with the food item. This technique was also used to reveal the substantial competitive advantage of Carcinus maenas over juvenile Cancer magister of equal size (McDonald et al. 2001). 
Despite the claim that Carcinus maenas will kill and consume Hemigrapsus oregonensis equal to themselves in size in the laboratory (Grosholz \& Ruiz 1995), this never occurred in our laboratory experiments nor during other work when the 2 species were placed together. During 854 and 768 h total of close confinement in shelter competition experiments between $C$. maenas, and $H$. oregonensis and $H$. sanguineus, respectively, there was no mortality or limb loss in either species of Hemigrapsus even though no food was provided. In 3 instances, juvenile C. maenas were consumed by $H$. sanguineus of equal or slightly smaller carapace width, and only one of these cases could be linked to molting by the C. maenas. Previous laboratory observations of C. maenas and $H$. sanguineus of equal size also revealed little or no antagonism (McDermott 1999). However, it is important to keep in mind the size-specific aspect of the CarcinusHemigrapsus relationship. Adult Carcinus in Bodega Bay Harbor can reach $96 \mathrm{~mm}$ in carapace width (pers. obs.), giving them a tremendous size advantage over adults of $H$. oregonensis and $H$. sanguineus which have maximum sizes of 49.5 and $43.9 \mathrm{~mm}$, respectively (Hart 1982, McDermott 1999). When artificially confined together, large Carcinus will sometimes prey on smaller $H$. oregonensis (Grosholz et al. 2000 pers. obs.).

Interspecific competition is frequently invoked as an explanation for differences in habitat use by sympatric species of decapods, but this seldom holds up under closer scrutiny. Careful examination of the interaction often reveals that physical factors such as substrate preferences (Teal 1958, Griffin 1971, Jensen \& Armstrong 1991), flow (Felgenhauer \& Abele 1983) or other microhabitat differences (Jones \& Simons 1982, McDonald 1982, Navarrete \& Castilla 1990) are of greater importance and may minimize direct competition. Since such differences in preference could have arisen either through past competition or via independent adaptation, the extent to which relationships were shaped by these mechanisms is impossible to determine. The expansion of these invasive decapods into new areas affords a chance to closely examine how use of habitat influences competitive interactions.

Invasion biology theory predicts a positive relation between native biodiversity and invasion resistance (Elton 1958). Yet, this has rarely been tested in the marine environment (Stachowicz et al. 1999). Many studies of invasions in marine habitats have instead focused on potential perturbations to native species or ecosystems and overlooked the role that native species may play in directly or indirectly limiting the impacts of these new arrivals. Carcinus maenas colonizing the west coast of North America are facing a far greater diversity of native crabs than did those on the east coast, when they expanded their range northward and had their greatest impact on bivalves and snails. Excluding C. maenas, only 9 species of crabs or crablike anomurans have been recorded from the intertidal zone of Maine (Williams 1984), while nearly $3 \times$ as many species (26) are found intertidally in Washington State (Jensen 1995) at the same approximate latitude. Many are potential predators and/or competitors of C. maenas, and there is evidence that large cancrids are limiting the distribution of adult C. maenas in some areas (McDonald et al. 1998). Similarly, juveniles of this species face competition for shelter with 3 native west coast grapsids, Hemigrapsus oregonensis, $H$. nudus, and Pachygrapsus crassipes, all of which are gregarious and occur in large assemblages beneath intertidal rocks. Unlike the 2 Hemigrapsus species, the latter is an aggressive species that readily consumes smaller crabs (Willason 1981). Given the apparent ability of $H$. oregonensis to exclude most juvenile $C$. maenas from habitat beneath rocks and the importance of such shelter to the survival of small crabs, we speculate that the presence of this and other species may indirectly limit $C$. maenas populations by making them more vulnerable to predators.

The combination of simple, easily replicated experiments and microhabitat sampling used here should be viewed as a starting point for further investigations. Direct experimental manipulations in the field, coupled with long-term monitoring programs, are clearly needed to document both the existence of competition and the consequences of such interactions to the fitness of the invading and resident species. However, given the tremendous recruitment variability of crabs, it would take many years of sampling to isolate such variability from the effects caused by a nonindigenous species. The techniques described here provide a means to rapidly assess some potential effects during the interim and quickly provide critical data to ecologists, resource managers, and policy makers concerned with the effects of nonindigenous species.

Acknowledgements. We are extremely grateful to Dr Charles Epifanio for providing laboratory space and equipment for the east coast work, and Dr Nancy O'Conner for help in locating potential study sites. We also thank the staff of Bodega Marine Laboratory, Bodega Bay, CA. Eva Mulder provided invaluable field assistance in Bodega Bay, Kevin Brink assisted with statistical analyses, and comments from Pamela Jensen, Curtis Roegner, and anonymous reviewers greatly improved the manuscript. This research was funded in part by a grant from Washington Sea Grant Program, University of Washington, pursuant to National Oceanic and Atmospheric Administration Award No. NA76RG0119, project R/ES-24. The views expressed herein are those of the authors and do not necessarily reflect the views of NOAA or any of its subagencies. Contribution Number 2146, Bodega Marine Laboratory, University of California at Davis. 


\section{LITERATURE CITED}

Abele LG, Campanella PJ, Salmon M (1986) Natural history and social organization of the semiterrestrial grapsid crab Pachygrapsus transversus (Gibbes). J Exp Mar Biol Ecol 104:153-170

Ahl RS, Moss SP (1999) Status of the nonindigenous crab, Hemigrapsus sanguineus, at Greenwich Point, Connecticut. Northeast Nat 6:221-224

Beck MW (1997) A test of the generality of the effects of shelter bottlenecks in four stone crab populations. Ecology 78:2487-2503

Behrens Yamada S, Boulding EG (1996) The role of highly mobile crab predators in the intertidal zonation of their gastropod prey. J Exp Mar Biol Ecol 204:59-83

Behrens Yamada S, Boulding EG (1998) Claw morphology, prey size selection and foraging efficiency in generalist and specialist shell-breaking crabs. J Exp Mar Biol Ecol 220:191-211

Bovbjerg RV (1970) Ecological isolation and competitive exclusion in two crayfish (Orconectes virilis and Orconectes immunis). Ecology 51:225-236

Byers JE (2000) Competition between two estuarine snails: implications for invasions of exotic species. Ecology 81: $1225-1239$

Caddy JF (1986) Modeling stock-recruitment processes in Crustacea: some practical and theoretical perspectives. Can J Fish Aquat Sci 43:2330-2344

Caldwell RL (1982) Interspecific chemically mediated recognition in two competing stomatopods. Mar Behav Physiol 8:189-197

Carlton JT, Geller JB (1993) Ecological roulette: the global transport of nonindigenous marine organisms. Science 261:78-82

Cohen AN, Carlton JT (1998) Accelerating invasion rate in a highly invaded estuary. Science 279:555-558

Cohen AN, Carlton JT, Fountain MC (1995) Introduction, dispersal and potential impacts of the green crab Carcinus maenas in San Francisco Bay, California. Mar Biol 122: 225-237

Crothers JH (1968) The biology of the shore crab Carcinus maenas (L.) II. The life of the adult crab. Field Stud 2:5 79-614

Dumbauld BR, Armstrong DA, McDonald TL (1993) Use of oyster shell to enhance intertidal habitat and mitigate loss of Dungeness crab (Cancer magister) caused by dredging. Can J Fish Aquat Sci 50:381-390

Elton CS (1958) The ecology of invasions by animals and plants. Methuen, London

Felgenhauer BE, Abele LG (1983) Ultrastructure and functional morphology of feeding and associated appendages in the tropical fresh-water shrimp Atya innocuous (Herbst) with notes on its ecology. J Crust Biol 3:336-363

Fernandez M, Iribarne O, Armstrong DA (1993a) Habitat selection by young-of-the-year Dungeness crab Cancer magister and predation risk in intertidal habitats. Mar Ecol Prog Ser 92:171-177

Fernandez M, Armstrong DA, Iribarne O (1993b) First cohort of young-of-the-year Dungeness crab, Cancer magister, reduces abundance of subsequent cohorts in intertidal shell habitat. Can J Fish Aquat Sci 50:2100-2105

Geller JB (1999) Decline of a native mussel masked by sibling species invasion. Cons Biol 13:661-664

Glude JB (1955) The effects of temperature and predators on the abundance of the softshell clam Mya arenaria in New England. Trans Am Fish Soc 84:13-26

Gollasch S (1999) The Asian decapod Hemigrapsus penicilla- tus (de Haan, 1835) (Grapsidae, Decapoda) introduced in European waters: status quo and future perspective. Helgol Meeresunters 52:359-366

Grant J, McDonald J (1979) Desiccation tolerance of Eurypanopeus depressus (Smith) (Decapoda: Xanthidae) and the exploitation of microhabitat. Estuaries 2:172-177

Griffin DJG (1971) The ecological distribution of grapsid and ocypodid shore crabs (Crustacea: Brachyura) in Tasmania. J Anim Ecol 40:597-621

Griffiths CL, Hockey P, Schurink CV, LeRoux PJ (1992) Marine invasive aliens on South African shores: implications for community structure and trophic functions. S Afr J Mar Sci 12:713-722

Grosholz ED, Ruiz GM (1995) Spread and potential impact of the recently introduced European green crab, Carcinus maenas, in central California. Mar Biol 122:239-247

Grosholz ED, Ruiz GM, Dean CA, Shirley KA, Maron JL, Connors PG (2000) The impacts of a nonindigenous marine predator in a California bay. Ecology 81:1206-1224

Hanks RW (1961) Chemical control of the green crab, Carcinus maenas (L.). Proc Natl Shellfish Assoc 52:75-86

Hart JFL (1982) Crabs and their relatives of British Columbia. Handbook 40. British Columbia Provincial Museum, Canada

Heck KL Jr, Thoman TA (1981) Experiments on predator-prey interaction in vegetated aquatic habitats. J Exp Mar Biol Ecol 53:125-134

Hockey PAR, van Erkom-Schurink C (1992) The invasive biology of the mussel Mytilus galloprovincialis on the southern African coast. Trans R Soc S Afr 48:123-140

Iribarne O, Armstrong DA, Palacios R, Fernandez M (1992) The ecological effects of adding bivalve shell to intertidal soft-bottom areas. Northwest Environ J 8:153-154

Jensen GC (1995) Pacific coast crabs and shrimps. Sea Challengers, Monterey

Jensen GC, Armstrong DA (1991) Intertidal zonation among congeners: factors regulating the distribution of porcelain crabs Petrolisthes spp. (Anomura: Porcellanidae). Mar Ecol Prog Ser 73:47-60

Jones MB, Simons MJ (1982) Habitat preferences of two estuarine burrowing crabs Helice crassa Dana (Grapsidae) and Macrophthalmus hirtipes (Jacquinot) (Ocypodidae). J Exp Mar Biol Ecol 56:49-62

Jousson O, Pawlowski J, Zaninetti L, Zechman FW, Dini F, DiGuiseppe G, Woodfield R, Millar A, Meinesz A (2000) Invasive alga reaches California. Nature 408:157-158

Klein-Breteler WCM (1976) Settlement, growth, and production of the shore crab, Carcinus maenas, on tidal flats in the Dutch Wadden Sea. Neth J Sea Res 10:354-376

Knudson JW (1964) Observations of the reproductive cycles and ecology of the common Brachyura and crablike Anomura of Puget Sound, Washington. Pac Sci 18:3-33

Kuris AM, Culver CS (1999) An introduced sabellid polychaete pest infesting cultured abalones and its potential spread to other California gastropods. Invertebr Biol 118: 391-403

LeRoux PJ, Branch GM, Joska MA (1990) On the distribution, diet, and possible impact of the invasive European shore crab Carcinus maenas (L.) along the South African coast. S Afr J Mar Sci 9:85-92

Lohrer AN, Whitlatch RB (1997) Ecological studies on the recently introduced Japanese shore crab (Hemigrapsus sanguineus), in Eastern Long Island Sound. In: Balcom NC (ed) Proc 2nd Northeast Conference on Nonindigenous Aquatic Nuisance Species. Connecticut Sea Grant College, University of Connecticut, Groton, p 49-60

Lohrer AN, Fukui Y, Wada K, Whitlatch RB (2000) Structural 
complexity and vertical zonation of intertidal crabs, with focus on habitat requirements of the invasive Asian shore crab, Hemigrapsus sanguineus (de Haan). J Exp Mar Biol Ecol 244:203-217

McDermott JJ (1991) A breeding population of the western Pacific crab Hemigrapsus sanguineus (Crustacea: Decapoda: Grapsidae) established on the Atlantic coast of North America. Biol Bull 81:195-198

McDermott JJ (1998) The western Pacific brachyuran (Hemigrapsus sanguineus: Grapsidae) in its new habitat along the Atlantic coast of the United States: geographic distribution and ecology. ICES J Mar Sci 55:289-298

McDermott JJ (1999) The western Pacific brachyuran Hemigrapsus sanguineus (Grapsidae) in its new habitat along the Atlantic coast of the United States: feeding, cheliped morphology and growth. In: Schram FR, von Vaupel Klein JC (eds) Crustaceans and the biodiversity crisis. Brill, Weiden, The Netherlands, p 425-444

McDonald J (1982) Divergent life history patterns in the cooccurring intertidal crabs Panopeus herbstii and Eurypanopeus depressus (Crustacea: Brachyura: Xanthidae). Mar Ecol Prog Ser 8:173-180

McDonald PS, Jensen GC, Armstrong DA (1998) Green crabs and native predators: possible limitations on the West Coast invasion. J Shellfish Res 17:1283

McDonald PS, Jensen GC, Armstrong DA (2001) The competitive and predatory impacts of the nonindigenous crab Carcinus maenas (L.) on early benthic phase Dungeness crab Cancer magister Dana. J Exp Mar Biol Ecol 258: 39-54

Moksnes PO, Pihl L, van Montfrans J (1998) Predation on postlarvae and juveniles of the shore crab Carcinus maenas: importance of shelter, size and cannibalism. Mar Ecol Prog Ser 166:211-225

Navarrete SA, Castilla JC (1990) Resource partitioning between intertidal predatory crabs: interference and refuge utilization. J Exp Mar Biol Ecol 143:101-129

Noël PY, Tardy E, D'Udekem D'Acoz C (1997) Will the crab Hemigrapsus penicillatus invade the coasts of Europe? C R Acad Sci Ser III Sci Vie Life Sci 320:741-745

O'Neill DJ, Cobb JS (1979) Some factors influencing the outcome of shelter competition in lobsters (Homarus americanus). Mar Behav Physiol 6:33-45

Palacios R, Armstrong DA, Orensanz J (2000) Fate and legacy of an invasion: extinct and extant populations of the softshell clam (Mya arenaria) in Grays Harbor (Washington). Aquatic Conserv: Mar Freshw Ecosyst 10:279-303

Peeke HV, Sippel J, Figler MH (1995) Prior residence effects in shelter defense in adult signal crayfish (Pacifastacus leniusculus (Dana)): results in same- and mixed-sex dyads. Crustaceana 68:873-881

Perkins-Visser E, Wolcott TG, Wolcott DL (1996) Nursery role of seagrass beds: enhanced growth of juvenile blue crabs (Callinectes sapidus Rathbun). J Exp Mar Biol Ecol 198: 155-173

Quayle DB (1988) Pacific oyster culture in British Columbia. Bull Fish Res Board Can 218:1-241

Race MS (1982) Competitive displacement and predation between introduced and native mud snails. Oecologia 54:337-347

Rangeley RW, Thomas MHL (1987) Predatory behavior of juvenile shore crab Carcinus maenas (L.). J Exp Mar Biol Ecol 108:191-197

Editorial responsibility: Otto Kinne (Editor) Oldendorf/Luhe, Germany
Richards RA (1992) Habitat selection and predator avoidance: ontogenetic shifts in habitat use by the Jonah crab Cancer borealis (Stimpson). J Exp Mar Biol Ecol 156:187-197

Ruiz GM, Carlton JT, Grosholz ED, Hines AH (1997) Global invasions of marine and estuarine habitats by nonindigenous species: mechanisms, extent, and consequences. Am Zool 37:621-632

Ruiz GM, Fofonoff P, Hines AH (1999) Non-indigenous species as stressors in estuarine and marine communities: assessing invasion impacts and interaction. Limnol Oceanogr 44:950-972

Soderback B (1991) Interspecific dominance relationship and aggressive interactions in the freshwater crayfishes Astacus astacus (L.) and Pacifastacus leniusculus (Dana). Can J Zool 69:1321-1325

Sousa WP (1993) Size-dependent predation on the salt-marsh snail Cerithidea californica Hademan. J Exp Mar Biol Ecol 166:19-37

Stachowicz JJ, Whitlatch RB, Osman RW (1999) Species diversity and invasion resistance in a marine ecosystem. Science 286:1577-1579

Taylor PR (1981) Hermit crab fitness: the effect of shell condition and behavioral adaptations on environmental resistance. J Exp Mar Biol Ecol 52:205-218

Teal JM (1958) Distribution of fiddler crabs in Georgia salt marshes. Ecology 39:185-193

Thiel M, Dernedde T (1994) Recruitment of shore crabs Carcinus maenas on tidal flats: mussel clumps as an important refuge for juveniles. Helgol Meeresunters 48:321-332

Thorpe JH (1976) Interference competition as a mechanism of coexistence between two sympatric species of grass shrimp Palaemonetes. J Exp Mar Biol Ecol 25:19-25

Trussell GC (1996) Phenotypic plasticity in an intertidal snail: the role of a common crab predator. Evolution 50:448-454

Vermeij GJ (1982) Phenotypic evolution in a poorly dispersing snail after arrival of a predator. Nature 299:349-350

Visser EP (1997) Competition, cannibalism, and prey limitation: factors compromising the effectiveness of shell habitat mitigation for early benthic phase Cancer magister in Grays Harbor, WA. PhD thesis, University of Washington, Seattle

Wahle RA, Steneck RS (1991) Recruitment habitats and nursery grounds of the American lobster Homarus americanus: a demographic bottleneck? Mar Ecol Prog Ser 69:231-243

Wainwright TD, Armstrong DA, Dinnel PA, Orensanz JM, McGraw KA (1992) Predicting effects of dredging on a crab population: an equivalent adult loss approach. Fish Bull US 90:171-182

Willason SW (1981) Factors influencing the distribution and coexistence of Pachygrapsus crassipes and Hemigrapsus oregonensis (Decapoda: Grapsidae) in a California salt marsh. Mar Biol 64:125-133

Williams AB (1984) Shrimps, lobsters, and crabs of the Atlantic coast of the eastern United States, Maine to Florida. Smithsonian Institution Press, Washington, DC

Williams AB, McDermott JJ (1990) An eastern United States record for the western Indo-Pacific crab, Hemigrapsus sanguineus (Crustacea: Decapoda: Grapsidae). Proc Biol Soc Wash 103:108-109

Wright HO (1968) Visual displays in brachyuran crabs: field and laboratory studies. Am Zool 8:655-665

Zar JH (1984) Biostatistical analysis, 2nd edn. Prentice Hall, Englewood Cliffs, New Jersey

Submitted: November 22, 2000; Accepted: June 7, 2001

Proofs received from author(s): January 3, 2002 